\title{
The Sexual Division of Household Labor
}

\author{
Thomas V. Frederick ${ }^{1}$, Jack O. Balswick ${ }^{2}$ \\ ${ }^{1}$ Marriage and Family Therapy Program, College of Psychology \& Counseling, Hope \\ International University, Fullerton, USA; \\ ${ }^{2}$ Fuller Theological Seminary, Pasadena, USA. \\ Email: tvfrederick@hiu.edu \\ Received April 27 $7^{\text {th }}, 2011$; revised May $17^{\text {th }}, 2011$; accepted June $25^{\text {th }}, 2011$.
}

\begin{abstract}
Mounting evidence from both historical and social-psychological perspectives is pointing to the conclusion that evangelicals are relying upon patriarchal gender ideologies, specifically the male breadwinner and female domestic family roles, as identity markers to distinguish themselves from others in mainstream America. One would expect that gender ideology as an identity boundary marker would have little to no effect on the actual gendered behavior of evangelicals. The evidence from this study supports this notion in that three gender ideology scales constructed of attitudinal items were utilized, with limited success, to understand their impact on the actual performance of household labors.
\end{abstract}

Keywords: Sexual Division of Household Labor, Social Group Identity, Subcultural Identity Theory

\section{Introduction}

Evangelicals have been known for their conservative religious beliefs, especially regarding their views of Scripture (Bartkowski, 2004; Ellison \& Bartkowski, 2002; Gallagher, 2003; Hunter, 1983, 1987; Smith, 2000; Smith et al., 1998). These religious beliefs have been used specifically as identity markers for evangelicals in both ethnographic and survey research. It is widely thought that these beliefs regarding Scripture are the central domain for evangelical religious identity.

Most types of research into evangelicalism logically begin with definitions. . For example, there are two basic theological tenets that Hunter $(1983,1987)$ has identified in theevangelical culture-Biblical inerrancy (The Bible is exclusively and exhaustively true) and concomitant methods of Biblical interprettation. These tenets have been developed and adopted by other researchers from history (Collins, 2005; Sweeney, 2005) and sociology of religion (Hunter, 1983, 1987; Webber, 1978).

However, both inside evangelical circles (Clapp, 1993; Lee, 1998; Van Leeuwen et al., 1993) and outside evangelical circles (Gallagher, 2003; Smith, 2000; Stacey, 1990), there is a growing consensus that the family is becoming a core identity issue for evangelicals. Evangelicals are becoming concerned over the "decline of the family" and the "crises of the family" (Smith, 2000) by which they mean a concern that divorce and postmodern family values are assaulting "the traditional family." Most evangelicals view this traditional family as the Biblical family; thereby, remaking the family values debate into a religiously charged discussion.

Another central tenet of evangelicalism is a critical engagement with American culture at large (Collins, 2005; Gallagher, 2003; Hunter, 1983, 1987; Smith, 2000; Smith et al., 1998; Sweeney, 2005). No place demonstrates this engagement more clearly than familial roles and ideologies. By maintaining a clear affirmation of male headship and female submission, evangelicals distinguish themselves from gains made by feminism and its elucidation of patriarchy (contra Stacey, 1990, who discusses the positive relationship between feminism and evangelicalism). An important aspect of male headship and female submission concerns the actual performance of household tasks. Of course, one should not assume a one-to-one correspondence between gender ideology and specific household tasks based on large, quantitative samples (Denton, 2004). By analyzing how evangelicals perform their household tasks, one may develop insight into how evangelicals may have modified their patriarchal views because of evangelicals' active engagement with feminism and family values in a negative sense, i.e., defining themselves against them.

\section{Secularization Theory and Its Discontents}

To begin with, Hunter $(1983,1987)$ has demonstrated that there has been a noticeable shift in views on Biblical inerrancy (The Bible is exclusively and exhaustively true) and concomitant methods of Biblical interpretation. The Bible is viewed as the true Word of God, but there are limits around the type or kind of truth contained in it. Along with a "high" view of Biblical inerrancy comes a literalistic hermeneutic. There has been a shift from a preference to always interpret the Bible literally to a preference to sometimes interpret the Bible figuratively.

The second theological shift Hunter (1987) identifies concerns doctrine. Doctrinally, evangelicals have shifted their perspectives on: 1) the devil-a personal being that directs evil forces, 2) anthropology-Adam and Eve were created by God for good, 3) cosmology-God created the earth, 4) soteriology-Christ is the only way for salvation, and 5) social justice-taking less precedence than evangelism. These views on scripture and doctrine demonstrate for Hunter a shift in the belief structure for evangelicals. Specifically, these shifts are evidence that views of scripture and doctrine have become modernized or secularized.

Hunter, therefore, argues for the increasing secularization of evangelicalism as it continues to interact with modern culture. Based on Berger (1967), Hunter views modernity as essentially subversive to all religious perspectives, especially Christianity. 
That is, modernity replaces the 'sacred canopy' of a religious worldview with a scientific, non-religious one. One of the central emphases in evangelicalism is lending to its own demise from a secularization perspective.

A core issue about evangelicalism from a secularization perspective is the robust nature of its existence. That is, evangelicalism is a growing, vibrant, worldwide religion that defies the expectations of secularization theory. Secularization posits that exposure to modernity erodes religious worldviews, in this case Evangelicalism. A contemporary theory used to explain evangelicalism's continued existence is Subculture Identity Theory (SIT) developed by Smith and colleagues (Smith, 2000, Smith et al., 1998). From a SIT perspective, three fundamental assumptions (Smith et al.) are: 1) everyone has a moral worldview, 2) worldviews are supported and maintained in actual social groups, and 3 ) religion naturally allows everyone to live by a worldview. These worldviews create symbolically defined boundaries, and they provide a way for determining who is and is not a member of the group, specifically who is and is not evangelical. For evangelicals, boundaries allow them to be embattled yet thriving (Smith et al., p. 121): The evangelical tradition's entire history, theology, and self-identity presupposes and reflects strong cultural boundaries with non- evangelicals; a zealous burden to convert and transform the world outside of itself; and a keen perception external threats and crises seen as menacing what it views to be true, good, and valuable.

\section{Purpose of the Present Study}

Focusing on evangelicalism's strong social dimensions naturally leads one away from theological discourse to social issues. One primary component of evangelicalism is the nature and role of the family in Christian life (Gallagher, 2003; Gallagher \& Smith, 1999; Lee, 1998). Therefore, this study utilizes Subcultural Identity Theory to understand changes in gender ideology over the course of two samples of Christianity Today (CT) readers, one in 1990 and one in 2001 and its role in actual family practices for evangelicals. CT markets itself to evangelicals of all denominational affiliations (CT website). We would argue that in addition to things like church attendance and holding to the infallibility of Scripture, subscribing to an evangelical periodical such as Christianity Today indicates a deeper level of participation and adherence to the evangelical worldview much like self-identification as a way of identifying Evangelicals (Smith et al., 1998).

Several hypotheses may be developed based on SIT. First, gender ideology is only minimally related to evangelical family practice. Gender ideology functions in evangelical circles as an identity marker, therefore, its purpose is to define and differenttiate insiders from outsiders. Household and parenting labors may have as their sources more pragmatic and task specific negotiations among relational partners as opposed to aspects of gendered identity or ideology. As a result of this sociological function, gender ideology may only be a minimally significant source for the domestic division of labor.

Second, education does not subvert or "secularize" evangelical gender ideology or its role in defining household and parenting tasks. From a SIT perspective, education may provide a proximal measure of evangelical's engagement with the culture, i.e., participation in social institutions. However, this participa tion in social institutions may actually strengthen, not weaken, the veracity of conservative evangelical gender ideology and the sexual division of household labors.

Finally, more pragmatic aspects of family life may be a more specific source for the domestic division of household and parenting labors for evangelicals. SIT would expect the actual negotiation of domestic tasks to be based on factors other than gender ideology. One would expect time demands placed by children, participation in the local congregation and education to be a more significant source for the division of household and parenting labors than gender ideology.

\section{Methods}

This study is based on secondary analysis of responses to gender ideology questions given by a randomly selected sample of Christianity Today readers in $1990(\mathrm{~N}=739)$ and $2001(\mathrm{~N}=$ 750). A secondary analysis is research conducted on a data set provided from another source. In the present study, Christianity Today surveyed its readership two different times. Each sample was obtained by randomly selecting on an " $n$ th" name based 1250 names from a list of all CT subscribers. One week before the mailing of the questionnaire, and three weeks following, postcards were mailed to encourage participation. The response rate was $59 \%$ and $60 \%$ for the 1990 and 2001 samples respectively. The unique advantages of this study is that it provides an understanding of evangelical gender ideology and domestic relationships based on a large sample of self-identified evangelicals from a major evangelical monthly periodical.

\section{Participants}

Women comprised most of the respondents of the 1990 cohort $(51.6 \%)$ compared with men $(48.1 \%)$ while almost half of the 2001 respondents were women $(43 \%)$ with a little over half being men $(53 \%)$. The average church size for respondents was 201 - 500 people for the 1990 cohort. Nearly one-third of the 2001 respondents attend a church with a size between $201-500$ members. For the 1990 cohort, $71.18 \%$ of women reported being a member of the laity, while $59.3 \%$ of men reported being a member of the laity. $95 \%$ of women and $71 \%$ of men serve in their local churches as members of the laity in the 2001 cohort: due to the large discrepancy between the 1990 and 2001 cohorts for this variable, clergy status will be used as a control variable. Wives in the 1990 cohort tend to be either unemployed temporarily $(14.5 \%)$ or not employed (25.9\%). Only. $2 \%$ of 1990 wives are employed full time, and .4\% of wives are employed part time; compared to $51 \%$ of all wives in 2001 cohort being employed: full time $(34 \%)$ or part time $(17 \%)$. $49 \%$ of 2001 wives are unemployed. $50.1 \%$ of husbands in the 1990 cohort are employed full time. Less than $20 \%$ of husbands in the 1990 cohort are not employed. $62 \%$ of 2001 husbands are employed full time. The average age of 1990 respondents was $41-50$ years. The average age of 2001 respondents is $51-60$ years. $34.2 \%$ of 1990 men have a seminary or other higher education, and $16.7 \%$ of them have a college degree. $18.9 \%$ of 1990 men have no college degree. For 1990 women, 37.9\% have no college education, while $25.1 \%$ have a college education. $11.6 \%$ of 1990 women have seminary or other higher education. $58.3 \%$ of 2001 husbands have a seminary or other higher education, while $28.4 \%$ of 2001 wives have seminary or 
college education. $28.9 \%$ of 2001 husbands and $40 \%$ of 2001 wives have a college education, and only $12.8 \%$ of 2001 husbands and $31.6 \%$ of 2001 wives have no college. The discrepancies for education and women's employment should have a predictable impact on gender ideology based on secularization theory (see below). The average 1990 cohort family income reported wasin the rage $\$ 40,000$ - $\$ 49,000$, and the 2001 cohort reported being more wealthy (range $\$ 60,000$ - \$74,999).

The demographics for the two samples were in general quite similar, except in regards to income, clergy status, and gender. The higher average income for the 2001 sample is to be expected as a reflection of the higher income for persons in the United States in general in 2001 than in 1990. However, since a greater percentage of the 2001 subjects were male $(53 \%$ to $48 \%$ in 1990) and laity rather than clergy ( $73 \%$ in 2001 to $60 \%$ in 1990), data analysis will control for gender and clergy/laity status.

\section{Measures}

\section{Gender Ideology Scales: Gender Role Attitudes Regarding Church, Theology, and Work}

Gender role attitude items were submitted to a Principal Components Factor Analysis (PCA) to explore their construct validity for the proposed gender ideology scales. In addition to Principal Components Factor Analysis, varimax rotation was utilized so that each factor is clearly separated and differentiated from the others (Kim \& Mueller, 1978). All data analysis utilized the Statistical Package for Social Sciences (SPSS) version 15.0.

The Gender Ideology Scale-Patriarchal Theology (GISPT) consists of the following four items: 1) God made men and women to be equal in personhood and value, but different in roles; 2) Both Adam and Eve were created in God's image, equal before God as persons and distinct in their manhood and womanhood, 3) The Bible affirms the principle of male headship in the family; and (21) Adam's headship in marriage was established by God before the Fall, and was not a result of $\sin$. The Theology of Gender scale demonstrates adequate a reliability $(\alpha=0.72)$.

The Gender Ideology Scale-Women's Role in the Church (GISWC) scale consists of the following four items: 1) only men should be ordained, 2) women may teach adult men and women in the church, 3) the position of deacon in the church should be held only by men, and 4) women should be silent in the church and not speak. The Women's Role in the Church scale demonstrates adequate a reliability $(\alpha=0.78)$. GIS-WC total score will be created by averaging responses to the 4 GIS-WC items.

The Gender Ideology Scale-Women's Involvement in Work (GISWW) scale consists of the following four items: 1) Promotion of women of child-bearing age should be limited because they may get pregnant, 2) Employers should provide women with maternity leave of at least three months with guarantees of the same or equal job upon return, 3) Women should receive equal pay for work that is equal to that of men, and 4) Working women with young children are less effective as employees. The Women's Involvement in Work scale demonstrates an adequate a reliability $(\alpha=0.81)$.

Scaling for the gender ideology scales used a $1-5$ point
Likert-type scale. Participants were asked to respond to each question by checking either strongly agree (5), agree (4), undecided (3), disagree (2), or strongly disagree (1). As the main measure is a social survey, the threat of test length on the consistency of findings is limited. As respondents are asked a variety of questions regarding both their beliefs about gender as well as their gender practices, consistency is measured statisticcally using internal consistency measures and scaling is based on factor analysis.

\section{Domestic Task Scale and the Parenting Task Scale: The Traditional Division of Domestic Labors}

Because the central concerns of this research concern the adoption of patriarchal gender role attitudes and the corresponding perceptions regarding the traditional division of household labor by CT readers, item scoring corresponds to the "traditional" (see Smith \& Reid, 1986); see also the "complementary approach" explicated by Piper and Grudem (1991) for a similar division of household labors) sexual division of household labor. That is, wives tend to do and take responsibility for daily, routine domestic tasks (Coltrane, 1997, 2000; Reid \& Smith, 1986), while husbands tend to do and take responsibility for less frequently performed domestic labors. That is, each household task will be scored as to who "should" do this task. This usually means that females are responsible for daily tasks (cooking, cleaning, dish washing) while males are responsible for less frequent outdoors types of tasks (automobile maintenance, yard work, house repairs).

Domestic task items were submitted to PCA factor analysis with varimax rotation to determine the existence of any underlying dimensions for the household labor items. Of the 12 household task items, 10 loaded very highly on 2 factors. The first factor will be identified as the Traditionally Women's Domestic Tasks Scale (TWDTS). The 6 items on this factor are: (1) Arranges and plans social activities, (2) Balances the checkbook, (3) Cooks meals, (5) Does the housework, (8) Goes grocery shopping, and (12) Takes out the garbage. These six items demonstrate adequate a reliability $(\alpha=0.74)$. The TWDTS will be averaged to create a total scale.

The second factor identified by the PCA will be identified as Traditional Men's Domestic Tasks Scale (TMDTS). The 4 items on this factor are: (7) Does the yard work, (9) Leads/ initiates devotions/Bible study, (10) Looks after and maintains the automobile(s), and (11) Makes major family/home decisions. These four items demonstrate adequate a reliability $(\alpha=$ 0.66 ). These four items will be averaged to create the TMDTS total scale.

The items used to construct the parenting task scale (PTS) are: (1) Administers discipline, (2) Cares for the children (dresses, feeds, bathes, etc.), (3) Changes diapers, (4) Coordinates children's schedule (music lessons, sports, visiting friends, etc.), (5) Gives attention to their spiritual growth and development, (6) Listens to their problems when they are hurting, (7) Manages the children's needs (buys clothes, handles doctor's visits, etc.), and (8) Plays with the children. Item scoring will reflect a traditional division of parenting tasks so that items (1) and (5) will be scored: 3 = mainly husband, $2=$ shared equally, and $1=$ mainly wife. Items (2), (3), (4), (6), and (7) will be scored: $3=$ mainly wife, 2 = shared equally, and $1=$ mainly husband.

The first factor will be identified as the Traditionally 
Women's Parenting Tasks Scale (TWPTS). The 5 items on this factor are: (1) Administers discipline, (2) Cares for the children (dresses, feeds, bathes, etc.), (3) Changes diapers, (4) Coordinates children's schedule (music lessons, sports, visiting friends, etc.), and (7) Manages the children's needs (buys clothes, handles doctor's visits, etc.). These five items demonstrate adequate a reliability $(\alpha=0.76)$. The TWPTS will be averaged to create a total scale.

The second factor identified by the PCA will be identified as Traditionally Men's Parenting Tasks Scale (TMPTS). The 3 items on this factor are: (5) Gives attention to their spiritual growth and development, (6) Listens to their problems when they are hurting, and (8) Plays with the children. These three items demonstrate adequate a reliability $(\alpha=0.66)$. These three items will be averaged to create the TMPTS total scale.

\section{Results}

Hierarchical regression analysis is used to model gender ideology's predictive ability on the traditional division of household and parenting labor. In addition to gender ideology, demographic variables - age, income, and years married - are also included to ascertain the single best predictor for the traditional division of labor. Sampling year and gender were also included in the regression analysis. 1990 (Cohort year) is coded so that larger numbers indicate 2001 and smaller numbers indicate 1990. Female (Gender) is coded so that larger numbers indicate males while smaller numbers indicate females. To index the time demands placed by children, the total score for each item "Number in Household for each age group (5 possible answers)" except for ages 18 years and over will be summed to create a time demand by children score (see Coltrane, 1997, Cowan \& Cowan, 1992; and Reid \& Smith, 1986 for the demanding role children place on families, even egalitarian ones).

Table 1 demonstrates the inter-relationships between gender ideology and education, church involvement, time demands, years married and income. It is important to note, that, there are

Table 1.

Correlations between Gender Ideology, Education, Time Demands from Children, Church Involvement, Years Married and Income.

\begin{tabular}{|c|c|c|c|c|c|c|c|c|}
\hline & \multicolumn{8}{|c|}{ Variables $^{\mathrm{a}}$} \\
\hline & 1 & 2 & 3 & 4 & 5 & 6 & 7 & 8 \\
\hline 1 & - & $0.32 * *$ & $0.50 * *$ & -0.04 & 0.04 & $-0.41 * *$ & -0.03 & -0.04 \\
\hline 2 & & - & $0.09 *$ & -006 & 0.03 & $-0.19 * *$ & -0.02 & -0.02 \\
\hline 3 & & & - & 0.01 & $-0.09 *$ & $-0.16 * *$ & 0.08 & 0.03 \\
\hline 4 & & & & - & -0.06 & 0.08 & -0.05 & -0.04 \\
\hline 5 & & & & & - & -0.09 & -0.07 & $0.25^{*}$ \\
\hline 6 & & & & & & - & -0.07 & -0.05 \\
\hline 7 & & & & & & & - & 0.04 \\
\hline 8 & & & & & & & & - \\
\hline
\end{tabular}

two sets of significant correlations. First, all gender ideology scales are significantly correlated. Second, church involvement accounts for $17 \%$ of the variance associated with GIS-WC, $4 \%$ of the variance associated with GIS-PT, and $3 \%$ of the variance associated with GIS-WW.

As can be seen in Table 2, demographic variables account for $17 \%$ of the variance associated with traditionally defined women's household tasks. In combining demographic variables with sampling year and gender, a total of $31 \%$ of variance associated with traditionally defined women's household tasks is accounted for. The predominant amount of variance associated with traditionally defined women's tasks is accounted for by demographic variables and sampling year and gender. Education, time demands from children, and church involvement account for no additional unique variance associated with traditionally defined women's household tasks when combined with demographic variables and sample year and gender. Gender ideology combined with all other variables accounts for $32 \%$ of the variance associated with traditionally defined women's household tasks indicating that gender ideology accounts for a significant amount of unique variance compared to education, time demands from children, and church involvement. However, gender ideology only contributes $1 \%$ of the unique variance accounted for in the regression models.

Table 2.

Hierarchical Regression Analyses for Variables Predicting Traditionally Defined Women's Household Tasks.

\begin{tabular}{|c|c|c|c|c|c|c|c|c|}
\hline \multirow{3}{*}{$\begin{array}{l}\text { Variables } \\
\text { Block } 1\end{array}$} & \multicolumn{8}{|c|}{ Regression Model ${ }^{\mathrm{a}}$} \\
\hline & \multicolumn{2}{|c|}{ Model 1} & \multicolumn{2}{|c|}{ Model 2} & \multicolumn{2}{|c|}{ Model 3} & \multicolumn{2}{|c|}{ Model 4} \\
\hline & B & SE B & B & SE B & B & SE B & B & SE B \\
\hline Age & -0.01 & 0.01 & -0.03 & 0.01 & -0.03 & 0.01 & -0.03 & 0.01 \\
\hline Income & -0.01 & 0.00 & 0.00 & 0.00 & 0.00 & 0.00 & 0.00 & 0.00 \\
\hline $\begin{array}{c}\text { Years } \\
\text { Married }\end{array}$ & 0.01 & 0.00 & 0.01 & 0.00 & 0.01 & 0.00 & 0.06 & 0.00 \\
\hline \multicolumn{9}{|l|}{ Block 2} \\
\hline $\begin{array}{l}\text { Sampling } \\
\text { Year }\end{array}$ & - & - & -0.31 & 0.02 & -0.32 & 0.02 & -0.26 & 0.02 \\
\hline Gender & - & - & 0.15 & 0.02 & 0.15 & 0.02 & 0.16 & 0.02 \\
\hline \multicolumn{9}{|l|}{ Block 3} \\
\hline Education & - & - & - & - & -0.001 & 0.01 & -0.001 & 0.01 \\
\hline $\begin{array}{c}\text { Time } \\
\text { Demands }\end{array}$ & - & - & - & - & 0.01 & 0.01 & 0.01 & 0.01 \\
\hline $\begin{array}{c}\text { Church } \\
\text { involvement }\end{array}$ & - & - & - & - & 0.00 & 0.00 & 0.00 & 0.00 \\
\hline \multicolumn{9}{|l|}{ Block 4} \\
\hline GISWC & - & - & - & - & - & - & -0.003 & 0.01 \\
\hline GISPT & - & - & - & - & - & - & 0.03 & 0.01 \\
\hline GISWW & - & - & - & - & - & - & -0.05 & 0.01 \\
\hline Constant & \multicolumn{2}{|c|}{2.00} & \multicolumn{2}{|c|}{2.16} & \multicolumn{2}{|c|}{2.12} & \multicolumn{2}{|c|}{2.06} \\
\hline Adjusted $\mathrm{R}^{2}$ & \multicolumn{2}{|c|}{0.17} & \multicolumn{2}{|c|}{0.31} & \multicolumn{2}{|c|}{0.31} & \multicolumn{2}{|c|}{0.32} \\
\hline$F$ change & \multicolumn{2}{|c|}{$145.76 * *$} & \multicolumn{2}{|c|}{$207.80 * *$} & \multicolumn{2}{|c|}{2.42} & \multicolumn{2}{|c|}{$9.45 * *$} \\
\hline
\end{tabular}


Demographic variables account for $22 \%$ of the variance associated with traditionally defined men's household tasks (see Table 3 ). A total of $32 \%$ of the variance associated with traditionally defined men's household tasks is accounted for when combining demographic variables with sampling year and gender. The predominant amount of variance associated with traditionally defined men's tasks is accounted for by demographic variables, sampling year and gender.

\section{Predicting the Traditional Division of Parenting Labor}

None of the gender ideology scales are significant predictors of traditionally defined women's parenting tasks (see Table 4). Demographic variables account for 5\% of the amount of variance associated with traditionally defined women's parenting tasks. An additional $32 \%$ of the variance associated with traditionally defined women's parenting tasks is accounted for by sampling year and gender. Education, time demands, and church involvement account for only an additional $2 \%$ of the variance associated with traditionally defined women's parenting tasks. Gender ideology scales account for no additional

Table 3.

Hierarchical Regression Analyses for Variables Predicting Traditionally Defined Men's Household Tasks.

\begin{tabular}{|c|c|c|c|c|c|c|c|c|}
\hline \multirow{3}{*}{$\begin{array}{c}\text { Variables } \\
\text { Block } 1\end{array}$} & \multicolumn{8}{|c|}{ Regression Modela ${ }^{a}$} \\
\hline & \multicolumn{2}{|c|}{ Model 1} & \multicolumn{2}{|c|}{ Model 2} & \multicolumn{2}{|c|}{ Model 3} & \multicolumn{2}{|c|}{ Model 4} \\
\hline & B & SE B & B & SE B & B & SE B & B & SE B \\
\hline Age & 0.07 & 0.01 & 0.04 & 0.01 & 0.04 & 0.01 & 0.04 & 0.01 \\
\hline Income & 0.02 & 0.00 & 0.00 & 0.00 & 0.00 & 0.00 & 0.00 & 0.00 \\
\hline $\begin{array}{l}\text { Years } \\
\text { Married }\end{array}$ & 0.08 & 0.00 & -0.06 & 0.00 & -0.06 & 0.00 & -0.06 & 0.00 \\
\hline \multicolumn{9}{|l|}{ Block 2} \\
\hline $\begin{array}{l}\text { Sampling } \\
\text { Year }\end{array}$ & - & - & 0.23 & 0.01 & 0.24 & 0.01 & 0.21 & 0.02 \\
\hline Gender & - & - & -0.04 & 0.02 & -0.02 & 0.01 & -0.04 & 0.02 \\
\hline \multicolumn{9}{|l|}{ Block 3} \\
\hline Education & - & - & - & - & -0.02 & 0.01 & -0.02 & 0.01 \\
\hline $\begin{array}{c}\text { Time } \\
\text { Demands }\end{array}$ & - & - & - & - & -0.01 & 0.01 & -0.01 & 0.01 \\
\hline $\begin{array}{c}\text { Church } \\
\text { involvement }\end{array}$ & - & - & - & - & -0.00 & 0.00 & -0.002 & 0.00 \\
\hline \multicolumn{9}{|l|}{ Block 4} \\
\hline GISWC & - & - & - & - & - & - & -0.02 & 0.01 \\
\hline GISPT & - & - & - & - & - & - & -0.03 & 0.01 \\
\hline GISWW & - & - & - & - & - & - & 0.04 & 0.01 \\
\hline Constant & \multicolumn{2}{|c|}{1.78} & \multicolumn{2}{|c|}{1.57} & \multicolumn{2}{|c|}{1.63} & \multicolumn{2}{|c|}{1.76} \\
\hline Adjusted $\mathrm{R}^{2}$ & \multicolumn{2}{|c|}{0.22} & \multicolumn{2}{|c|}{0.32} & \multicolumn{2}{|c|}{0.32} & \multicolumn{2}{|c|}{0.33} \\
\hline F change & \multicolumn{2}{|c|}{$196.77 * *$} & \multicolumn{2}{|c|}{$150.70^{* *}$} & \multicolumn{2}{|c|}{$3.54 *$} & \multicolumn{2}{|c|}{$8.41 * *$} \\
\hline
\end{tabular}

$\mathrm{a}^{*}=\mathrm{p} \leq 0.05 ; * * \mathrm{p} \leq 0.001$.
Table 4.

Hierarchical Regression Analyses for Variables Predicting Traditionally Defined Women's Parenting Tasks.

\begin{tabular}{|c|c|c|c|c|c|c|c|c|}
\hline \multirow{3}{*}{$\begin{array}{c}\text { Variables } \\
\text { Block } 1\end{array}$} & \multicolumn{8}{|c|}{ Regression Model ${ }^{\mathrm{a}}$} \\
\hline & \multicolumn{2}{|c|}{ Model 1} & \multicolumn{2}{|c|}{ Model 2} & \multicolumn{2}{|c|}{ Model 3} & \multicolumn{2}{|c|}{ Model 4} \\
\hline & $B$ & $S E B$ & $B$ & $S E B$ & $B$ & $S E B$ & $B$ & $S E B$ \\
\hline Age & -0.01 & 0.01 & -0.02 & 0.01 & -0.02 & 0.01 & -0.02 & 0.01 \\
\hline Income & 0.00 & 0.00 & -0.002 & 0.00 & -0.003 & 0.00 & -0.003 & 0.00 \\
\hline $\begin{array}{l}\text { Years } \\
\text { Married }\end{array}$ & 0.05 & 0.01 & 0.04 & 0.00 & 0.04 & 0.00 & 0.04 & 0.00 \\
\hline \multicolumn{9}{|l|}{ Block 2} \\
\hline $\begin{array}{l}\text { Sampling } \\
\text { Year }\end{array}$ & - & - & -0.05 & 0.02 & -0.06 & 0.02 & -0.05 & 0.02 \\
\hline Gender & - & - & 0.58 & 0.02 & 0.56 & 0.02 & 0.56 & 0.02 \\
\hline \multicolumn{9}{|l|}{ Block 3} \\
\hline Education & - & - & - & - & 0.07 & 0.01 & 0.07 & 0.01 \\
\hline $\begin{array}{c}\text { Time } \\
\text { Demands }\end{array}$ & - & - & - & - & -0.003 & 0.01 & -0.01 & 0.01 \\
\hline $\begin{array}{c}\text { Church } \\
\text { involvement }\end{array}$ & - & - & - & - & -0.002 & 0.00 & -0.002 & 0.01 \\
\hline \multicolumn{9}{|l|}{ Block 4} \\
\hline GISWC & - & - & - & - & - & - & -0.01 & 0.01 \\
\hline GISPT & - & - & - & - & - & - & 0.01 & 0.00 \\
\hline GISWW & - & - & - & - & - & - & -0.001 & 0.01 \\
\hline Constant & \multicolumn{2}{|c|}{1.67} & \multicolumn{2}{|c|}{0.99} & \multicolumn{2}{|c|}{0.91} & \multicolumn{2}{|c|}{0.91} \\
\hline Adjusted $\mathrm{R}^{2}$ & \multicolumn{2}{|c|}{0.05} & \multicolumn{2}{|c|}{0.37} & \multicolumn{2}{|c|}{0.39} & \multicolumn{2}{|c|}{0.39} \\
\hline$F$ change & \multicolumn{2}{|c|}{$33.59^{* *}$} & \multicolumn{2}{|c|}{$544.14 * *$} & \multicolumn{2}{|c|}{$17.66^{*}$} & \multicolumn{2}{|c|}{0.94} \\
\hline
\end{tabular}

a. $\mathrm{p} \leq 0.05 ; * *=\mathrm{p} \leq 0.001$.

variance associated with traditionally defined women's parenting tasks.

Demographic variables account for $14 \%$ of the variance associated with traditionally defined women's household tasks. In combining demographic variables with sampling year and gender, a total of $21 \%$ of variance associated with traditionally defined women's household tasks is accounted for. The predominant amount of variance associated with traditionally defined women's tasks is accounted for by demographic variables and sampling year and gender (see Table 5).

Education, time demands from children, and church involvement account for $.3 \%$ additional unique variance associated with traditionally defined women's household tasks when combined with demographic variables and sample year and gender. Gender ideology combined with all other variables accounts for $22 \%$ of the variance associated with traditionally defined men's parenting tasks. However, gender ideology only contributes $1 \%$ of the unique variance accounted for in the regression models.

To summarize the regression analyses, the evidence indicates that the gender ideology scales account for $1 \%$ of the unique 
Table 5 .

Hierarchical Regression Analyses for Variables Predicting Traditionally Defined Men's Parenting Tasks.

\begin{tabular}{|c|c|c|c|c|c|c|c|c|}
\hline \multirow{3}{*}{$\begin{array}{c}\text { Variables } \\
\text { Block } 1\end{array}$} & \multicolumn{8}{|c|}{ Regression Models ${ }^{\mathrm{a}}$} \\
\hline & \multicolumn{2}{|c|}{ Model 1} & \multicolumn{2}{|c|}{ Model 2} & \multicolumn{2}{|c|}{ Model 3} & \multicolumn{2}{|c|}{ Model 4} \\
\hline & $B$ & $S E B$ & $B$ & $S E B$ & $B$ & $S E B$ & $B$ & $S E B$ \\
\hline Age & 0.04 & 0.01 & 0.03 & 0.01 & 0.02 & 0.01 & 0.02 & 0.01 \\
\hline Income & 0.00 & 0.00 & -0.01 & 0.00 & -0.01 & 0.00 & -0.01 & 0.00 \\
\hline $\begin{array}{l}\text { Years } \\
\text { Married }\end{array}$ & -0.08 & 0.00 & -0.06 & 0.00 & -0.06 & 0.00 & -0.06 & 0.00 \\
\hline \multicolumn{9}{|l|}{ Block 2} \\
\hline $\begin{array}{l}\text { Sampling } \\
\text { Year }\end{array}$ & - & - & 0.19 & 0.02 & 0.20 & 0.02 & 0.12 & 0.02 \\
\hline Gender & - & - & -0.18 & 0.02 & -0.18 & 0.02 & -0.19 & 0.02 \\
\hline \multicolumn{9}{|l|}{ Block 3} \\
\hline Education & - & - & - & - & 0.02 & 0.01 & 0.03 & 0.01 \\
\hline $\begin{array}{c}\text { Time } \\
\text { Demands }\end{array}$ & - & - & - & - & -0.02 & 0.01 & -0.01 & 0.01 \\
\hline $\begin{array}{c}\text { Church } \\
\text { involvement }\end{array}$ & - & - & - & - & 0.00 & 0.00 & 0.01 & 0.00 \\
\hline \multicolumn{9}{|l|}{ Block 4} \\
\hline GISWC & - & - & - & - & - & - & 0.00 & 0.01 \\
\hline GISPT & - & - & - & - & - & - & -0.01 & 0.01 \\
\hline GISWW & - & - & - & - & - & - & 0.07 & 0.01 \\
\hline Constant & \multicolumn{2}{|c|}{2.26} & \multicolumn{2}{|c|}{2.28} & \multicolumn{2}{|c|}{2.24} & \multicolumn{2}{|c|}{2.17} \\
\hline Adjusted $\mathrm{R}^{2}$ & \multicolumn{2}{|c|}{0.14} & \multicolumn{2}{|c|}{0.206} & \multicolumn{2}{|c|}{0.209} & \multicolumn{2}{|c|}{0.22} \\
\hline$F$ change & \multicolumn{2}{|c|}{$111.79 * *$} & \multicolumn{2}{|c|}{$91.92 * *$} & \multicolumn{2}{|c|}{$3.95 *$} & \multicolumn{2}{|c|}{$12.48 * *$} \\
\hline
\end{tabular}

a. $\mathrm{p} \leq 0.05 ; * *=\mathrm{p} \leq 0.001$.

variance associated with traditionally defined women's and men's household tasks. Gender ideology also accounts for $1 \%$ of the unique variance associated with traditionally defined men's parenting tasks. Gender ideology does not contribute any unique variance to traditionally defined women's parenting tasks. Demographic variables account for the predominant amount of variance associated with domestic labor.

\section{Discussion}

One of the questions this study attempted to answer centered on the relationship between gender ideology and gendered division of household and parenting tasks. Our strategy was to consider the ability of each of the 3 aspects of gender ideology to predict each of the 4 types of family tasks, relative to other potential explanatory variables.

Subcultural Identity theory provides an excellent description of how a social group develops its identity as compared with a larger cultural identity. In the present study, SIT has provided specific hypotheses as to the role gender and religion play in aiding Evangelical Christians to develop and maintain a distinct identity from the larger culture in the United States.

\section{Gender Ideology as Related to Evangelical Family Practice}

From the above findings it can be concluded that gender ideology is very minimally related to patterns of gender divisions of household and parenting labor. It should be noted, however, that there is a definite high, positive correlation between church involvement and gender ideology as measured by the proposed scales. This may indicate that church involvement and gender ideology may in fact be measuring a similar construct. Therefore, it may be concluded that gender ideology may play a larger role in explaining the variance associated with household and parenting tasks as measured by the $\mathrm{CT}$ survey. Combining the total amount of variance of all regression models accounts for only $32 \%$ of the variance associated with traditionally defined women's household tasks; this is an important finding because of the strong conventional wisdom within evangelicalism that behavior follows from attitudes (Balswick, 1987). Indeed, the major division between more conservative and more liberal Christians during the civil rights movement was that the former believes that the heart must be changed before discriminatory behavior will change, while liberals put their energies into attempts to change discriminatory practices (Balswick, 1987)

\section{Secularization as Potential Explanation for Gender Ideology: Education and the Prediction of Household Labor}

Based on secularization theory, one would expect level of education to be inversely related to traditional gender ideology and familism (Berger, 1967; Coltrane, 1997; Hunter, 1983, 1987). Since the 2001 cohort of CT readers had higher levels of education, especially differences among 1990 and 2001 women, than the 1990 cohort, it would be expected that this alone might result in gender ideology for the 2001 cohort being less traditional than the 1990 cohort. The fact that this is not the case seems to rule out the usefulness of secularization theory in interpreting our results. Increases in evangelical women's education and employment are related to decreased tolerance for women's participation in the church and the workplace. It is noteworthy that of the 3 arenas of gender ideology identified in this study - gender and the church, gender and work outside of the home, and gender and theology - the latter is the least related to gendered divisions of household and parenting tasks. This is an irony, since, due to their high view of Scriptural authority, evangelicals seek to support and justify their behavior on the basis of the teachings of scripture. Yet, when it comes to gender participation in housework and parenting, ecclesiastical and work world ideologies are better predictors than theological ideology. But even more of an irony is that certain structural variables - such as years married and education - appear to be better predictors of traditional division of household and parenting tasks than is gender ideology. These findings indicate that gender ideology defined in terms of attitudinal statements is only minimally related to the actual practices of evangelicals.

\section{Pragmatic Aspects of Family Life as a Source for the Domestic Division of Household and Parenting Labors}

These findings are consistent with those reported by Gallagher (2003) regarding the relationship between views of Scrip 
ture and holding to male headship or mutual submission in marriage. Using the Religious Identity and Influence Survey (Smith et al., 1998), Gallagher (2003) operationalized view of Scripture as an aspect of gender ideology. The evidence suggests that both gender essentialist (strong male headship language) and biblical feminists (mutual submission language) equally share very high views of Scripture and its authority for individual believers as a rule in faith and practice (Gallagher). Further, evangelicals do not tend to solely appeal to hermeneutics in arguing either for or against their gender ideology and concomitant domestic labors (Bartkowski, 1996, 2001; Gallagher, 2003; Gallagher \& Smith, 1999). In daily life of actually performing domestic labors, evangelicals in Gallagher's study rely upon other ways to negotiate who does what. Gallagher confirms for this study that theologically informed gender ideology is not the most significant source for the domestic division of traditional labors for evangelicals.

Gallagher (2003) suggests three options for how evangelicals distribute household and parenting labor. First, the traditionalist approach is to maintain the male breadwinner and female domestic division of household and parenting labor where females take primary responsibility for all domestic tasks and males "help" with the housework. This could also characterize the complementary approach (Piper, 1991). Second, domestic tasks are more pragmatically divided based on male headship which emphasizes servant leadership thereby encouraging males to participate in all household and parenting tasks. Finally, egalitarians also encourage the equal division of domestic labors; however, they do not adopt male headship language in the discussion of negotiating domestic tasks. However, it does seem that CT readers are following Gallagher's second approach in apportioning domestic labor because all relevant variables only account for $32 \%$ of the variance associated with household and parenting tasks at best. Due to the reification of patriarchal gender ideologies (Frederick \& Balswick, 2006) and gender ideology's minimal ability to significantly predict the traditional division of domestic labor, it would seem that CT readers, along with most other evangelicals, utilize a more pragmatic approach to negotiating the domestic division of labor alongside the continued affirmation of the traditional family model.

The evidence from CT readers does support gender ideology as being a significant source in how evangelicals perceive the traditional division of household and parenting tasks. The evidence, however, also suggests that education, time demands, and church involvement may play a more significant role in the distribution of domestic labor than does gender ideology. In considering the efficacy of the proposed gender ideology scales for predicting the traditional division of household and parenting labors, one should consider the unique variance that GIS variables contribute to the total amount of variance accounted for in the regression models. The GIS scales contribute $1 \%$ of unique variance for traditionally defined women's and men's household tasks and traditionally defined men's parenting tasks. The $1 \%$ unique variance contributed by the GIS indicates that it is of slight importance as a predictor of household and parenting tasks. It could be the case that education, time demands, and church involvement may measure similar constructs to the GIS. The evidence also indicates that gender ideology is highly related to church involvement. Taken together, gender ideology, education, church involvement, time demands account for a significant amount of variance associated with domestic labors.

\section{Conclusions and Limitations}

There are three major conclusions based upon the findings from this study. To begin with, there is evidence for the multidimensional nature of gender ideology. There is mixed evidence in general regarding the efficacy of gender ideology predicting the sexual division of domestic labor in contrast to relative resources and time demands (Bianchi et al., 2000; Coltrane, 1997, 2000; Kroska, 2000, 2002; Pleck, 1981). Gender ideology, it is assumed, assesses the extent to which an individual agrees or disagrees with statements regarding male and female roles which indicates one's gender ideology. At one time, gender ideologies were assumed to constitute one's gender identity; however, gender identity measures do not necessarily measure one's maleness or femaleness (Pleck, 1981). Gender ideology measures, however, do "tend to capture the extent to which people express agreement or disagreement with conventional gender stereotypes" (Coltrane, 1996/1997, p.158). There is actually little to no evidence for gender ideology scales and indices of actually measuring an aspect of identity which may explain the lack of relatedness between gender ideology and identity to actual gender behavior. For evangelicals, gender ideology may consist of attitudes and preferences regarding the nature of manhood and womanhood as well as church and workforce participation. In addition, the behaviors associated with one's gender role forms an experiential dimension to gender ideology that must be taken into account. Evangelical's gender ideology necessarily extends to both household and parenting tasks. In operationalizing gender ideology, one would do well to have a multidimensional construct taking into account as many facets of gender ideology as possible.

Second, the major findings from this study may indicate the adoption of the family as a central aspect of evangelical gender ideology - especially as an identity boundary maintenance strategy (SIT). Gender ideology and behavior within the evangelical subculture is not uniform; however, and there is evidence that differences between the 1990 and 2001 cohorts are not uniform either. It is significant, for example, that the 1990 sample of women are most traditional in defining men's household tasks, while in the 2001 sample it is the men themselves who hold to the most traditional view on household tasks. This may indicate that evangelicals affirm a traditional family and gender ideology while they perceive domestic labor along different lines (Pragmatic Egalitarianism-Gallagher).

Finally, this study demonstrates the effectiveness of SIT for understanding Christianity Today readers' gender ideology and domestic division of labor. By 1) having a multidimensional construct for gender ideology, 2) accounting for education and the potential for testing a secularization theory hypothesis against a SIT one, and 3) the result in line with theoretical predictions that gender ideology is minimally related to the actual performance of household tasks, all point to the efficacy of SIT for this sample of evangelical Christians.

Evangelicals are a heterogeneous group. This study has found that at least some evangelicals adopt patriarchal language to discuss their preferred family model and its concomitant gender ideologies; however, this model is applied in individual relationships in a myriad of ways (Bartkowski, 2001). As with 
non-evangelical, non-religious samples, relative resources, gender ideology and time availability play a complex role in explaining the sexual division of household labor (Coltrane, 1997). There is no clear-cut single best explanation for the ways in which evangelicals negotiate the tasks that form the most intimate gendered relationship (Bartkowski, 2001).

\section{References}

Balswick, J. O. (1987). The psychological captivity of Evangelicalism. In W. H. Swatos, Jr. (Ed.), Religious Sociology: Interfaces and Boundaries (pp. 141-152). West Port, CT: Greenwood Press.

Bartkowski, J. P. (1996). Beyond Biblical literalism and inerrancy: Conservative Protestants and the interpretation of Scripture. Sociology of Religion, 57, 259-272. doi:10.2307/3712156

Bartkowski, J. P. (2001). Remaking the Godly marriage: Gender negotiation in Evangelical families. Rutgers, NJ: Rutgers University Press.

Bartkowski, J. P. (2004). The Promise Keepers: Servants, soldiers, and Godly men. New Brunswick, NJ: Rutgers University Press.

Berger, P. L. (1967). The sacred canopy: Elements of a sociological theory of religion. New York, NY: Anchor Books.

Bianchi, S. M., Milkie, M. A., Sayer, L. C., \& Robinson, J. P. (2000). Is anyone doing the housework? Trends in the gender division of household labor. Social Forces, 79, 191-228. doi:10.2307/2675569

Christianity Today. (2004). "Christianity Today- Informing. Inspiring. Connecting. Equipping.” Accessed March 10, 2004

[http://www.christianitytoday.com/].

Clapp, R. (1993). Families at the crossroads: Beyond traditional and modern options. Downers Grove, IL: InterVarsity Press.

Collins, K. J. (2005). The Evangelical moment: The promise of an American religion. Grand Rapids, MI: BakerAcademic.

Coltrane, S. (1997). Family man: Fatherhood, housework, and gender equity. New York, NY: Oxford University Press.

Coltrane, S. (2000). Research on household labor: Modeling and measuring the social embeddedness of routine family work. Journal of Marriage and the Family, 62, 1208-1233. doi:10.1111/j.1741-3737.2000.01208.x

Cowan, C. P., \& Cowan, P. A. (1992). When partners become parents: The big life change for couples. New York: Basic Books.

Denton, M. (2004). Gender and marital decision making: Negotiating religious ideology and practice. Social Forces, 82, 1151-1180. doi:10.1353/sof.2004.0034

Ellison, C. G., \& Bartkowski, J. P. (2002) Conservative Protestantism and the division of household labor among married couples. Journal of Family Issues, 23, 950-985. doi:10.1177/019251302237299

Frederick, T. V., \& Balswick, J. O. (2006). Evangelical gender ideology: A view from Christianity Today readers. Journal of Religion and Society, 8, 1-12.

Gallagher, S. K. (2003). Evangelical identity and gendered family life.
New Brunswick, NJ: Rutgers University Press.

Gallagher, S. K., \& Smith, C. (1999). Symbolic traditionalism and pragmatic egalitarianism: Contemporary evangelicals, families, and gender. Gender \& Society, 13, 211-233. doi: $10.1177 / 089124399013002004$

Hunter, J. D. (1983). American Evangelicalism: Conservative religion and the quandary of modernity. New Brunswick, NJ: Rutgers University Press.

Hunter, J. D. (1987). Evangelicalism: The coming generation. Chicago, IL: University of Chicago Press.

Kim, J. O., \& Mueller, C. W. (1978). Factor analysis: Statistical methods and practical issues (Vol. 07014). Newbury Park, CA: Sage Publications.

Kroska, A. (2000). Conceptualizing and measuring gender ideology as an identity. Gender \& Society, 14, 368-394. doi: $10.1177 / 089124300014003002$

Kroska, A. (2002). Does gender ideology matter? Examining the relationship between gender ideology and self- and partner- meanings. Social Psychology Quarterly, 65, 248-265. doi:10.2307/3090122

Lee, C. (1998). Beyond family values. Grand Rapids, MI: InterVarsity Press.

Piper, J. (1991). A vision of Biblical complementarity: Manhood and womanhood defined according to the Bible. In J. Piper \& W. Grudem (Eds.). Recovering Biblical Manhood and Womanhood: A Response to Evangelical Feminism (pp. 31-59). Wheaton, IL: Crossway.

Pleck, J. H. (1981). The myth of masculinity. Cambridge, MA: Massachusetts Institute of Technology Press.

Robinson, J. R. (1985). The validity and reliability of diaries versus alternative time use measures. In F. Thomas and F. P. Sanford (Eds.), Time, Goods, and Well-Being (pp. 33-62). Ann Arbor, MI: Institute for Social Research, University of Michigan.

Smith, C. (2000). Christian America? What Evangelicals really want. Los Angeles, CA: University of California Press.

Smith, C., with Emerson, M., Gallagher, S. K., Kennedy, P., and Sikkink, D. (1998). American Evangelicalism: Embattled and thriving. Chicago, IL: University of Chicago Press.

Smith, A. D., \& Reid, W. J. (1986). Role-Sharing marriage. New York, NY: Columbia University Press.

Stacey, J. (1990). Brave new families: Stories of domestic upheaval in late twentieth-century America. New York, NY: BasicBooks.

Sweeney, D. A. (2005). The American Evangelical story: A history of the movement. Grand Rapids, MI: Baker Academic.

Van Leeuwen, M. S., Knoppers, A., Koch, M. L., Schuurman, D. J., \& Sterk, H. M. (1993). After Eden: Facing the challenge of gender reconciliation. Grand Rapids, MI: Eerdmans.

Webber, R. E. (1978). Common roots: A call to Evangelical maturity. Grand Rapids, MI: Zondervan.

Wilcox, W. B. (2004). Soft patriarchs, new men: How Christianity shapes fathers and husbands. Chicago: University of Chicago Press. 